Будрайтскис И. Б. Что «удерживает» катехон? Конечность государства в консервативной и социалистической мысли // Философия. Журнал Высшей школы экономики. 2021. - T. 5, № 2. - C. 13-33.

\title{
ИЛЬЯ БУАРАЙТСКИС*
}

\section{ЧТО «УАЕРЖКИАЕТ» КАТЕХОН? КОНЕЧНОСТЬ ГОСУААРСТВА В КОНСЕРВАТИВНОЙ И СОЦИАЛИСТИЧЕСКОЙ МЫСЛИ**}

Получено: 04.03.2021. Рецензировано: 20.03.2021. Принято: 31.03.2021.

Аннотация: Понятие «катехон» («удерживающий»), представляющее исключительное значение как для теологической традиции, так и для политической философии Нового времени, как известно, берет свое начало из 2-го послания Фессалоникийцам Апостола Павла. Эта «удерживающая» наступление последних времен сила часто отождествлялась с Римской империей, а впоследствии - с христианским имперским государством, охраняемое пространство которого давало возможность для распространения Благой вести. Такая миссия «удержания», с одной стороны, наделяла государство сакральным значением, но с другой- обозначала его конечность и несовершенство. Удерживая время, катехон не снимает, но сохраняет противоречия и гетерогенность, принимая свою незавершенность как бремя собственной миссии. В секуляризованном виде «сдерживающее» государство принимает общество как антагонистическое пространство борьбы и конфликта, а функция политической власти связывается с установлением временного равновесия, имеющего исторически обусловленные и относительные формы. Аля консервативной мысли государство-катехон удерживало общество от унифицирующего равенства и рационализации, а человека-от иллюзии совершенства и моральной гармонии. Понимание государства как силы, возвышающейся над разрозненными элементами общества и удерживающего его от органически присущего ему хаоса, находилось и в основе марксистской концепции государства. В предлагаемой статье с опорой на широкий круг авторов (Т. Гоббса, К. Маркса, К. Шмитта, К. Леонтьева, А. Агамбен) рассмотрены консервативные и левые интерпретации государства, различным образом принимающие идею катехона, а также ее интерпретации, не связанные напрямую с понятием государственной власти.

Ключевые слова: катехон, политическая теология, эсхатология, марксизм, консерватизм, секуляризация, бонапартизм, цезаризм.

DOI: $10.17323 / 2587-8719-2021-2-13-33$.

Понятие «катехон» («удерживающий»), представляющее исключительное значение как для теологической традиции, так и для политической философии Нового времени, берет свое начало из 2-го послания

*Будрайтскис Илья Борисович, преподаватель, Московская высшая школа социальных и экономических наук; старший научный сотрудник, Центр современных политических исследований ИОН РАНХиГС (Москва), ibudraitskis@gmail.com, ORCID: 000о-00030781-849X.

**(C) Будрайтскис, И. Б. (C) Философия. Жуурнал Высшей школы экономики. 
Фессалоникийцам Апостола Павла. Эта «удерживающая» наступление последних времен сила часто отождествлялась с Римской империей, а впоследствии - с христианским имперским государством, охраняемое пространство которого давало возможность для распространения Благой вести.

Такая миссия «удержания», с одной стороны, наделяла государство сакральным значением, но с другой- обозначала его конечность и несовершенство. В отличие от секулярного государства модерна, государствокатехон не могло «осуществиться» и достигнуть идеального состояния. Удерживая время, катехон не снимает, но сохраняет противоречия и гетерогенность, принимая свою незавершенность как бремя собственной миссии.

В консервативной мысли государство-катехон преимущественно рассматривалось как сила, сдерживающая общество от унифицирующего равенства и рационализации, а человека - от иллюзии совершенства и моральной гармонии. В секуляризованном виде «сдерживающее» государство (начиная с Гоббса) принимает общество как антагонистическое пространство борьбы и конфликта, а функция политической власти связывается с установлением временного равновесия, имеющего исторически обусловленные и относительные формы.

Понимание буржуазного государства как силы, возвышающейся над разрозненными элементами общества и удерживающей его от органически присущего ему хаоса, также находилось в основе политической концепции Маркса. Однако конфликт «неупорядоченного общества» и оформляющего его государственного порядка для марксистов разрешался через реализацию истории и преодоление тайны времени. Если для консерваторов неизбежная конечность государства не была расположена в историческом времени и оставалась скрытой от человеческого знания, то для марксистов она связывалась с радикальным преобразованием общества, у которого отпадает потребность в государстве. Тем не менее растворению государства в рационально организованном (т. е. социалистическом обществе) должен был предшествовать этап пролетарской диктатуры, в которой «сдерживающая», репрессивная роль государства открыто предъявляет себя и, таким образом, обозначает свой временный и конечный характер.

Восходящее к Апостолу Павлу представление о катехоне ясно указывает на его эсхатологического противника - Антихриста, искушающего людей предложением ложного социального единства и морального порядка. Дистопический образ унифицированного общества, в котором 
подлинные цели человека оказываются утрачены и подчинены безличным механизмам, также находился в центре как консервативной, так и левой критики модерна. Катехон, таким образом, может удерживать и от подобного ложного единства, сохраняя пространство конфликта и перспективу финальной социальной трансформации (или коллективного искупления).

В этой статье я хотел бы показать, как идея «катехона» оказывается принципиальной как для консервативной, так и для социалистической критики секулярного (буржуазного) государства. Это утверждение, однако, не столько доказывает парадоксальное сближение правой и левой перспективы, сколько раскрывает неоднозначность и амбивалентность самого катехона.

\section{КАТЕХОН: АМБИВАЛЕНТНОСТЬ ПОНЯТИЯ}

Значение понятия «катехон» у Апостола Павла является предметом огромной и продолжающейся дискуссии, связанной как с тем, что именно подразумевалось под «сдерживающей» силой (Peerbolte, 1997), так и с вопросом о том, в чем было его практическое значение для религиозного сообщества в Фессалониках, к которому обращался Павел (Horsley, 1997; Rumlu, 2010). Если объект «удержания» ясен - это дьявол, сила которого, «тайна беззакония», уже разворачивает свое действие во времени, - то субъект, замедляющий время, чтобы предотвратить торжество Антихриста, не называется по имени открыто. Впрочем, само содержание посланий Павла Фессалоникийцам призвано «сдержать» эсхатологические ожидания, которые в прямом, неопосредованном виде неизбежно вели к открытому политическому конфликту с римскими властями (ibid.; White, 2019). Сохраняя обещание близящегося Царства Божьего, идея «катехона» обосновывала необходимое место существующего государства в апокалиптическом сценарии. Однако место Рима в этом сценарии вступало в явное противоречие с его собственной идеей как образа неподвижной вечности, тогда как миссия «катехона» была ограничена отмеренным ему временем. «Катехон» лишь предваряет подлинное вечное Царство, но при этом является необходимым условием его осуществления. Таким образом, «катехон» как бы замещает имя, прямое произнесение которого приведет к активации конфликта между двумя царствами, за одним из которых стоит языческое и а-историческое представление о времени, а за другим-эсхатологическое и мессианское. 
Если в традиции патристики одновременно принималось два различных толкования «катехона»-как Святого духа и как силы государства, - то позднее «государственная» интерпретация начинает преобладать (Peerbolte, 1997: 141). Амбивалентность «катехона», с одной стороны обосновывавшая историческую миссию имперского государства, а с другой - подразумевавшая его «надмирный», сакральный характер, иногда приводила к смешению двух планов. Так, в византийской средневековой традиции мотив «последнего императора» (сразившего в финальной битве дьявола и затем уступившего свой престол Христу) накладывался на мотив «победоносного императора» (мессию, спустившегося с небес, чтобы победить Антихриста) (Kraft, 2012). С похожим смешением вечного и временного, катехонического и мессианского, связана и двойная природа короля в Западной Европе, в частности описанная в классической работе Эрнста Канторовича (Канторович, Бойцов и Серегина, 2015).

Таким образом, катехон, обозначавший конечность государства, мог трансформироваться в оправдание надвременного характера последнего. Эта амбивалентность «катехона» уже в Новое время находит свое отражение в гоббсовском «Левиафане». Описанный Гоббсом тип общественного договора, перманентно сдерживающего естественное «право меча», исходящее от противостоящих друг другу индивидов, в целом соответствует секулярной версии государства-катехона. Постоянная близость «естественного состояния», которое гражданское временно подавляет, но не преодолевает окончательно, явно напоминает о постоянной близости Апокалипсиса, действительный момент наступления которого остается неизвестным. Однако ключевым для концепции Гоббса является отсутствие у этого государства какой-либо трансцендентной миссии - напротив, оно лишено собственного тела и представляет лишь опосредованную силу реальных индивидуальных тел, добровольно обменявших свободу на безопасность.

Для Карла Шмитта в самой операции секуляризации катехона, которую производит Гоббс, уже содержится потенция его разрушения. Обратной стороной государства как пустого механизма ( «искусственного человека»), не имеющего других оснований, кроме аффекта страха, становится девальвация «государственной этики» в пользу партикулярных интересов отдельных групп, «вырывающих куски мяса» из его земного суверенного тела (Шмитт, Кузницын, 2006). Могущество Левиафана оказывается иллюзорным, так как оно исключает государство из моральной борьбы за душу подданного, ограничиваясь его внешним 
подчинением и, таким образом, обозначая границы индивидуальной «негативной свободы». Такое государство обречено в силу своего сугубо материального характера и позиции морального нейтралитета - оно не может исполнить подлинную функцию катехона.

Однако исключение трансцендентного момента в обосновании суверенитета для Гоббса совсем не означает исключения Бога из мира. Напротив, суверенное и божественное полностью совпадают, так как Бог определяется Гоббсом как действующая первопричина установления общественного договора. Церковь («царство тьмы») и пророчество больше не могут опосредовать отношения человека и Бога, воля которого теперь прямо соответствует содержанию закона. Присутствие Бога в мире выражается исключительно в интуициях «естественного разума», предписывающего подчинение суверену. Это подчинение основано на рациональном страхе перед реальностью наказания, который для Гоббса соответствует «страху божьему» (Manenschijn, Vriend, 2012: 45).

У государства-Левиафана нет сакральной миссии, непонятной людям - наоборот, тождество божественной и суверенной воли познается через рациональный «естественный разум». Для Гоббса не существует никаких институтов, представляющих волю Бога, кроме государства. Модель этого тождества он находит в ветхозаветном пророчестве, которое одновременно являлось и трансляцией божественной воли, и законодательным актом: «Царство Божие есть гражданское царство, состоявшее прежде всего в обязанности народа Израиля подчиняться тем законам, которые Моисей принес ему с горы Синай» (Гоббс, Гутерман, 2001: 277).

Таким образом, секуляризированный катехон Гоббса превращается из «сдерживания» времени в его мессианскую реализацию-т. е. непосредственное Царство Божие на земле. Гражданское и естественное, хаос и порядок, Левиафан и Бегемот здесь сливаются в борьбе, в которой нет победителей и устанавливается равновесие, утверждающее а-историческую и прямую власть суверена. Задачи этого государства не ограничены временем конца, так как антагонистические силы общества и дисциплинирующая их сила государства вместе производят гражданский порядок (Prozorov, 2017). Джоржио Агамбен отмечает, что сдерживание времени (безопасность) и его динамика (акселерация) в таком государстве сходятся, а «приостановка» и «развитие» уже не противостоят друг другу как политические стратегии (Agamben, 2015).

Гоббс осуществляет «радикальную приватизацию христианской веры, предназначенную для легитимации абсолютной власти секулярного 
правителя» (Manenschijn, Vriend, 2012: 56). Определяя политику как предельно последовательную реализацию христианства, Гоббс превращает религию в неотъемлемый элемент политики. Можно сказать, что Гоббс производит операцию, прямо противоположную «политической теологии» (по крайней мере, в том значении, в котором она использовалась в XX веке): это не обнаружение в политике трансцендентного плана («сверх-натурализации натурального» (Milbank, 2006: 230), но, напротив, опрокидывание трансцендентного в политическое. Таким образом, политическое лишается своего исторического и «сдерживающего» характера.

«Левиафан» Гоббса может привести и к консервативной легитимации государства (т.е. исторической и «сдерживающей» дурную человеческую природу), и к либеральной (рациональной и а-исторической), причем каждая из версий восходит к описанной выше амбивалентности катехона.

\section{КАТЕХОН И ГОСУДАРСТВО МОДЕРНА}

В разных версиях секуляризация «катехона»-т. е. обнаружение в государстве модерна нерационализируемого остатка, тайны Провиденияс ХIX века становится одним из принципиальных элементов европейской консервативной политической мысли. Например, Карл Шмитт полагал, что если средневековая христианская империя была «властью с поручением», которая «осознает свой собственный конец», то государство Нового времени определяет себя исключительно через пространственный порядок (Шмитт, Лощевский и Коринец, 2008: 35). Границы власти, которые прежде были связаны отпущенным свыше историческим временем, теперь ограничиваются пространством. Так, государство, перестав быть формой удержания времени, становится формой удержания пространства.

Однако современные государства, лишившись качества «исторической силы» и превратившись в цезаризм - чистую форму без содержания, тем не менее через пространство продолжают сдерживать и время, создавая различные порядки «плюриверсума», хрупкого равновесия по отношению друг к другу. Более того, для Шмитта само политическое становится главной формой удержания конфликта внутри человека и общества, а значит, и продолжающегося со-присутствия греха и благодати в мире. Политическое, определяемое через борьбу, противостоит мертвящей силе универсализации мира. Смысл «катехона» состоит в сохранении тайны времени, сопротивлении прогрессу и любым версиям 
революционной телеологии. Это форма сохранения неравенства и противоречий, которые соединяются, а не снимаются через нечто третье (Шмитт, Коринец, 2000: 108). На пути стремящейся от «действительности к понятию» силе бесформенного - то есть мира, освобожденного от присутствия Бога,- встают формы государства. В пространственном порядке и законах войны секулярных государств- так же, как прежде в средневековой христианской империи,- - заключено спасение времени от «эсхатологического паралича, тормозящего любое свершающееся в человеческом мире событие» (Шмитт, Лощевский и Коринец, 2008: 35).

Катехонический государственный порядок не претендует на совершенство - идеальную модель, воплощенную вне времени и пространства. Государство осознает свой временный характер и принадлежность историческим обстоятельствам. Именно поэтому Шмитт восстает против кантианской идеи права, максима которого, как и внутренний нравственный закон, существует как бы за пределами времени и пространства этого мира. Напротив, для Шмитта содержание закона активно проявляет себя как «решение», расположенное во времени и принадлежащее времени (Шмитт, Коринец, 200о). Право не нейтрально по отношению к миру, погруженному в борьбу, но является частью этой борьбы и поэтому полностью определяется конкретной ситуацией (Wilson, 2019: 81).

Несмотря на то что государство модерна, в отличие от христианской империи, является цезаристским - то есть формой, лишенной внутренней миссии, - его содержание может быть обнаружено в момент «решения». Таким образом, в наследии Шмитта можно найти глубокую (хотя и не лишенную противоречий) (Wilde, 2011) взаимосвязь представлений о «сдерживающем» государстве и «чрезвычайном положении» как проявлении подлинного содержания закона через его разрушение в качестве нейтральной нормы.

Для Шмитта процесс изгнания божественной тайны из мира последовательно обращается в процессе изгнания тайны из государства, финальной рационализации последнего и его растворения в обществе, свободном от противоречий, - то есть в процесс стремления к реализации кантианского предположения о возможности гармонии внутреннего убеждения и внешней правовой нормы. Таким образом, преодоление политики как формы конфликта, соответствующего состоянию падшего человечества, и его подмена этикой - т. е. «христианством без Христа» (Соловьев, 1988: 698), низведенным до качества соответствующего законам разума морального учения,- - ничто иное, как программа Антихриста, предлагающего людям избавление от страданий в обмен на 
отказ от действительного Христа, распятого и воскресшего в мире. Для Владимира Соловьева государство, сохраняющее свою необходимость как инструмент войны, придающий форму межгосударственным противоречиям, отвечает самому состоянию «христова мира, основанного на разделении... между добром и злом» и охраняет его от «смешения... того, что внутренне враждует между собой» (Соловьев, 1988: 698).

\section{РОССИЙСКИЙ ИМПЕРСКИЙ КАТЕХОН}

В традиции русской консервативной мысли ХІх века Российская империя оставалась подлинным, не-секуляризованным катехоном - государством с миссией, стоявшим на пути западного рационализма и революционного стремления к равенству. Для «консервативной утопии» славянофилов главным преимуществом русского общества было ровно то, что так беспокоило Шмитта,- отсутствие формы, единство внешнего и внутреннего, присущее народному религиозному сознанию (Валицкий, 2019: 236). Это органическое монархическое православное сознание большинства составляло альтернативу не только западному рационализму, но и самой истории (основанной на гегельянской диалектике субъектного и субстанциального, личностного и надличностного). Российская империя с ее бескрайними просторами и до-гражданскими отношениями между государством и гетерогенным населением выпадала из пространственного порядка, описанного Шмиттом. Это государство не только не вступило в современность, но и было готово бросить ей вызов.

Так, Константин Леонтьев полагал, что «мировое назначение» России заключается в сдерживании «народов на пути безверия, наиболее позднего наступления последних времен». Сдерживая «антихристианский прогресс», Россия способна осуществить свою миссию не столько благодаря принципу монархии, сколько в силу неравенства и сословности самого общества. Катехон противопоставляет истории, стремящейся к своему осуществлению (т. е. Апокалипсису), остановившееся социальное время, неподвластное рационализации (Леонтьев, 2012: 101).

Государство-катехон, основанное на божественном поручении, остается не-умопостигаемым для своих подданных. Его действия должны быть приняты, но не могут быть до конца поняты и приведены в соответствие с рассудком. Такое государство сохраняет тайну времени и секрет собственной конечности, и поэтому его значение не может исчерпываться рациональным гражданским контрактом, принадлежащим настоящему. 
Эпоха революций и распространения демократии, с точки зрения крайних русских консерваторов, давала ясные свидетельства «сгущения» апокалиптических признаков. Например, для Иоанна Кронштадтского Апокалипсис оставался не безусловной реальностью, но угрожающей возможностью, которую можно и должно сдержать. Эта миссия лежит на православном царстве- России, которая последовательно стояла на пути у любых попыток установления мирового правительства Антихриста. Концепция России как катехона, развернутая в книге Кронштадского «Начало и конец нашего земного мира» (Сергиев, И. И. [Иоанн Кронштадтский], 1900), во многом и сегодня остается актуальной для мировоззрения консервативных элементов православного сообщества (Кирилл [Патриарх Московский и всея Руси], 2018).

Рост апокалиптических проявлений в современную эпоху для Иоанна Кронштадтского имеет диффузный и универсальный характер. На смену конкретным, видимым носителям воли дьявола приходит дух времени, практически любое выражение которого соответствует признакам грядущего конца времен. Отклонение от истины, изгнание Бога из мира превращаются в новую норму. «Человек-зверь сделался обычным явлением культурной жизни», насильственное и сатанинское содержание которой проявляется через «искусство, технику и право эксплуатации через рекламу и обман на законном основании». Божественная воля замещается новым идолом - народом, «уполномочившим представителей принять принадлежащую ему, этому идолу, власть». Все это сообщает о приближении конца света, но никак не определяет точный момент, который остается «сокровенной тайной». Сила Откровения Иоанна состоит в том, что повествует о судьбе мира не из какой-либо точки его истории: «пророк, стоя на высоте вечности, не знает времени, пред ним все сливается в одно настоящее» (Сергиев, И. И. [Иоанн Кронштадтский], 1900: 7).

Показательно, что для Иоанна Кронштадтского представление о катехонической миссии российского государства связано с тем, что Россия никогда не была частью Римской империи и не причастна к античному наследию. Напротив, дьявольский дух современности основан на возрождении этого наследия, построенного на чувственности и власти моды. Еще важнее, что Россия не может участвовать в восстановлении Римской империи, которое является необходимым условием для всемирного господства Антихриста. Российская монархия остается христианским катехоном, государством с миссией, тогда как дьявол может 
победить благодаря торжеству цезаристской власти, преодолевшей порядок пространственных границ и получившей всемирный характер.

Таким образом, с консервативной точки зрения секулярное цезаристское государство Нового времени само по себе не является катехоном, но может стать либо предисловием для грядущей универсальной империи Антихриста, либо, наоборот, неосознанно превратиться в силу, сдерживающую Антихриста.

\section{БОНАПАРТИЗМ И МАРКСИСТСКАЯ ТЕОРИЯ ГОСУДАРСТВА}

Линия критики секулярного, «пустого» государства, ошибочно воспринимающего себя как завершенную идеальную форму, существующую по ту сторону времени, удивительным образом сближает консервативную и марксистскую перспективы. В своем анализе капитализма и его политических институтов Маркс выступает как «деконструктор» секулярного порядка (Milbank, 2006: 177), природный и научно обусловленный характер которого оказывается лишь тотальной идеологической иллюзией. Эта иллюзия носит бессознательный, практический характер («культа без догматики», по определению Вальтера Беньямина (Беньямин, 2012: 100) и приводит к перманентному самообману. Это относится как к представлению о саморегулируемом рынке, управляемом квази-природными законами, так и к идее рационального либерального государства. Так же как за «естественным» рыночным порядком скрывается анархия производства и потенциальность разрушительных кризисов, секулярное государство, лишенное представления о своем ограниченном и несовершенном характере, является лишь формой, сдерживающей нарастающую классовую борьбу. С этой позиции программа «демократической республики», восходящая к наследию Французской революции, у Маркса с самого начала вызывает глубокий скепсис, так как буржуазное государство лишь заменяет религию в качестве посредника между «человеком и свободой человека» (Маркс, Прейс, 1955: 389). Правовое государство мыслит себя в качестве осуществленного и универсального, тогда как на самом деле представляет ограниченную форму господства одного класса.

Поражение республиканских иллюзий в 1848 году, с точки зрения Маркса, приводит к реализации не иллюзорного (эмансипации человека), но действительного содержания (пустотного и технического) буржуазного государства в бонапартистской диктатуре. Мощная бюрократическая машина этого государства, возвышаясь над обществом, пытается встать на пути у истории, развивающейся через конфликты 
и противоречия. Бонапартизм уничтожил все партии ради торжества одной де-идеологизированной «партии порядка», программа которой исчерпывалась необходимостью любой ценой сдержать хаос (Маркс, Гольдман и Тер-Акопян, 1956а: 127).

Тем не менее для Маркса бонапартизм самообманывается относительно своей вечности, так как в действительности не сдерживает ход времени, но является необходимым этапом для реализации его целипостисторического безгосударственного коммунизма. В этом смысле он становится подлинным «катехоном», так как его мнение о собственной вечности и «стабильности» является лишь частью масштабной реализации логики истории. Более того, бюрократическое государство, возвышающееся над своими элементами, является формой, в которой кризис капитализма и политического господства буржуазии приходит к своему крайнему выражению (там же: 206). Рост производительных сил и политического самосознания пролетариата внутри этой формы, временно сдерживающей открытое противостояние классов, в итоге приводит к краху бонапартизма и первому опыту действительного преодоления государства в Парижской коммуне. Просуществовавшая тогда всего два месяца диктатура пролетариата представляла из себя принципиально иной тип государства, которое открыто осознавало свою историческую и классовую ограниченность - и как излишек, остаток нерациональных общественных отношений должно было раствориться по мере рационализации общества.

Пролетарское государство, выполняя функцию прямого насильственного обеспечения классовой власти, «сдерживающей» попытки реванша свергнутых классов, демаркирует границу между социальным и политическим. Оно уже не выступает как целое, сверху удерживающее вместе гетерогенные детали, но дает возможность самому обществу прийти к новому состоянию единства. Таким образом, «отмирающее» пролетарское государство становится «катехоном» с раскрытой тайной, а необходимость его существования оказывается обусловлена лишь необходимостью его исчезновения. Чем дальше пролетарское государство сохраняет себя, тем больше оно наполняет свое «катехоническое» самооправдание экономическими, геополитическими или моральными задачами (как это наглядно видно из трансформации официального языка советского государства с 1930-х гг.). Такое государство начинает все больше воспринимать себя не только как средство, но и как цель.

Однако для того чтобы сохранять свою роль чистого средства, пролетарское государство не должно относиться к себе как к морально 
нейтральному инструменту, при помощи которого можно осуществить переход из исторического состояния борьбы в постисторическое состояние социальной гармонии. Моральный конфликт должен быть перенесен внутрь самой субъектности государства и его аппарата. Государство, как явление, принадлежащее к дисгармонии старого мира, необходимо в принципе понимать как искажение, зло, и его использование для преодоления искаженного положения вещей оказывается ничем иным, как «изгнанием сатаны руками Вельзевула» (Лукач, Земляной и Гусев, 2010: 10). Стоит вспомнить, что этот образ, заимствованный Георгом Лукачем из Евангелия, имеет следующее продолжение: «если сатана сам себя изгоняет, то разделится сам с собой: как же устоит царство его?» (Мф. 12:26) Отмирающее государство, декларируя себя как необходимое и обреченное на исчезновение зло, производит такую постоянную операцию внутреннего разделения. Рабочее государство, если можно так сказать, в отличие от бессознательно катехонических государств прошлого, становится катехоном, наделенным самосознанием, а значит практически приближающим свой неизбежный конец.

\section{АНТИХРИСТ КАК ИНСТИТУТ}

Если катехон представляет государство, принимающее свою историческую конечность и несовершенство, то антихрист, приход которого катехон сдерживает, напротив, декларирует создание универсального и совершенного государственного порядка. Это царство тотального контроля и калькуляции, где целое определяет все встроенные в него элементы. Обещая реализацию всеобей свободы, антихрист на деле утверждает систему абсолютного рабства, в которой человек лишается подлинной внутренней свободы - т. е. выбора между добром и злом. Страх перед государством, претендующим на вечность и благо, сопровождал историческое христианство со времен Римской империи, однако приобрел особое значение в период становления модерного рационального государства. Начиная с эпохи Реформации антихрист в значительной мере лишается образа личности и начинает рассматриваться как институт (Williamson, 2008: 43). В Новое время централизация государства и его секуляризация - от петровской России до наполеоновской Франции - часто опознавались религиозными критиками как верные признаки приближающегося антихриста. Они не сообщают точного знания о наступлении конца света, однако детализируют черты его приближения, описанные в Откровении Иоанна. 
Сергей Булгаков, один из наиболее тонких православных интерпретаторов Откровения, отмечал, что предсказание Апокалипсиса не синхронизировано с реальными историческими событиями и «имеет силу над временем как его внутренняя норма» (Булгаков, 2014: 30). Это пророчество, которое наполняет время, не исчерпывая его смысл и сохраняя тайну его конца. Поэтому, с точки зрения Булгакова, хх век достоверно не является «последним временем», однако его опыт тоталитаризма открывает смысл рассказа об антихристе. Тотальное государство, представляющее себя как реализацию всей человеческой истории, становится апофеозом «земного царства», которое противостоит небесному царству Христа. Если Шмитт находит в цезаристском государстве современности возможность обрести иное, катехоническое содержание, Булгаков прямо отождествляет это государство с антихристом. Отбрасывая христианское понимание ограниченного характера земной власти, «цезаризм (фюрерство) наших дней как русского, так и германского типа по-своему является... параллелью Римскому абсолютизму» (там же: 119). За его пустой, механизированной формой скрывается подлинная цель - духовное опустошение мира, то есть имманентизация данного и полное изгнание божественного начала. Если в христианском государстве с его временным и ограниченным характером было необходимо «наличие известного духовного равновесия, при котором оно не выходило за пределы своих правовых целей», то цезаристское государство «превращается в зверя, когда оно за эти пределы выходит» (там же: 128).

Интересное развитие эсхатологическая рамка тоталитаризма находит у Джузеппе Форнари, который рассматривает противостояние Христа и антихриста как конфликт между Культурой и Цивилизацией, в котором первая связана с динамическим и политическим началом, а вторая - с мертвой механической формой. Тотальное государство цивилизации, преодолев все внутренние противоречия, проявляет себя лишь вовне - через агрессивную военную экспансию, целью которой является полное уничтожение соперника. Истребление внутренних врагов в тоталитарном государстве также имеет принципиально антиполитический характер, так как разрушает сам принцип конкретной вины. Массовые репрессии осуществляются против групп, наций и классов, тогда как вина их отдельных представителей не имеет значения. Уничтожение другого производится не для преодоления «миметического нагнетания» (трансформации энергии насилия «всех против всех» в насилие «всех против одного») (Жирар, Лукьянов и Хмелевская, 2015: 32), так как осуществляется не обществом, но безличной государственной машиной. 
Лишаясь свободной воли, все в тоталитарном обществе становятся жертвами. Даже тоталитарный лидер, претендующий на место спасителя, также является жертвой-как Иисус, лишенный божественной природы, он превращается в воплощение Сатаны (Fornari, 2010: 54). Представляя пародию на Христа, тоталитарный лидер действительно мыслит себя как спаситель человечества, а его личность и надличностная миссия сливаются до неразличимости. Во всем множестве своих конкретных воплощений антихрист остается нерефлексирующим орудием зла, а не его сознательным проводником, так как он, в отличие от Христа, лишен свободы и действует как чистая необходимость.

В «Трех разговорах о войне, прогрессе и конце всемирной истории» Владимира Соловьева для того чтобы исполнить неоконченную миссию Христа, антихрист собирается на место «воздаятельной правды» эсхатологического обещания поставить «распределительную» правду реализованного всеобщего блага (Соловьев, 1988: 723). Царство антихриста с его обещанием «равенства всеобщей сытости» легко представлялось консервативным интерпретаторам как практически осуществленная социалистическая утопия. Так, Сергей Булгаков прямо проводил параллель между предсказанием о числе зверя («никому нельзя будет ни покупать, ни продавать, кроме того, кто имеет это начертание») и огосударствлением экономики. Это «порабощение через карточную и тикетную систему распределения хозяйственных благ для удовлетворения насущных потребностей», характерное для плановой или кейнсианской экономики (Булгаков, 2014: 133).

Развитие этой линии может предполагать и интерпретацию рыночной свободы как продолжения свободы выбора, утверждающей присутствие Христа в мире и стоящей на пути распределительной экономики антихриста. Вероятно, именно в такой связи можно найти одно из объяснений идеологического союза секулярного и скептического либертарианства и христианского фундаментализма в Америке последних десятилетий. «Большое правительство», осуществляющее вмешательство в экономику и заменяющее истину общины верующих абстрактным законом, переводится на уровень религиозных представлений как признак грядущего Антихриста (и соответствует мессианскому нарративу республиканских администраций Рейгана и Буша-мл.) (Williamson, 2008: 318).

Однако социалистическая критика власти денег как всеобщего эквивалента, лишающего уникальности и свободы каждую отдельную личность, также может соответствовать царству Антихриста, предваряющего конец света. Предлагаемое им ложное равенство «под видом 
признания человека» «оказывается, скорее, лишь последовательным проведением отрицания человека, поскольку сам человек... стал сам этой напряженной сущностью частной собственности» (Маркс, Брушлинский и др., 1956b: 582).

В своей «Великой трансформации» Карл Поланьи утверждал, что рыночная экономика, в Новое время встроившая многообразие живых социальных связей в надличностную универсальную систему, создала цивилизацию, обреченную на гибель. Если капиталистическая система была «сатанинской мельницей», перемалывающей общество на изолированные существования, лишенные личностного начала, то социализм становился

продолжением той попытки превратить общество в систему исключительно человеческих, личностных связей, которая в Западной Европе всегда ассоциировалась с христианской традицией (Поланьи, Васильев и Федоров, 2015: 254).

Однако в концепции Поланьи капиталистическая «цивилизация ХІх века» не являлась гомогенной и завершенной, но, напротив, была отмечена постоянной борьбой двух разнонаправленных тенденций (или «двойным движением») (там же: 9о):

...c одной стороны рынки подчинили себе весь мир... с другой, система соответствующих мер сложилась в мощные институты, призванные контролировать воздействие рынка на труд, землю и деньги.

Таким образом, общество, сопротивлявшееся поглощению рынком в самых разнообразных формах - от государственного протекционизма до рабочего движения, - представляло собой силу, «сдерживавшую» рыночную экспансию. Этот гетерогенный социальный «катехон» противостоял наступлению «последних времен», когда окончательное разрушение связей, основанных на признании человека как цели, а не средства экономики, могло привести к тотальной войне и полному растворению личности в производстве. Поланьи рассматривал фашизм именно как программу такого поглощения человеческой свободы рыночным механизмом, где индивид окончательно превращается в деталь дегуманизированного «коллектива» (Polanyi, 2010).

Во многом близкое Поланьи понимание фашизма как предельной формы капиталистического производства разделял немецкий марксистский политический теоретик Франц Нойманн (Нойманн, Быстров, 2015). Согласно Нойманну, немецкий нацизм представляет собой не апофеоз 
рационального государства (гоббсовского Левиафана), а его противоположность - Бегемота. В таком порядке насилие не исключается благодаря праву, но полностью заменяет его в качестве единственного способа господства высших классов. Для Нойманна нацизм представляет собой прямую власть капитала, который уже не нуждается в государстве как опосредующей силе. Это господство организованного хаоса стало возможным, так как коллективная воля германского монополистического капитала уничтожила Веймарскую республику, в которой социал-демократы и организованное рабочее движение, опираясь на гарантированные демократические права, могли «сдерживать» интересы работодателей.

Так, ложное единство Антихриста, предваряющее наступление «последних времен», в социалистической мысли трансформируется в анализ фашизма как окончательного торжества капиталистической тотальности, неизбежно связанной с беспощадным насилием империалистической войны. А функцию «катехона» выполняют рабочее движение и демократические институты, способные сдержать человечество на пути капиталистической деградации и коллективного самоубийства.

\section{ЗАКЛЮЧЕНИЕ}

В этой статье я постарался дать самый краткий обзор критики современного (секулярного) государства справа и слева, в которой представление о его ограниченной во времени и несовершенной природе наследует теологическому понятию «катехона». Эта критика приобретает особое значение в настоящий момент, когда резкое укрепление государства в период пандемии как силы, способной гарантировать спасение человеческой жизни и реализовать общие интересы, вновь ставит вопрос о границах государственного вмешательства и их политического обоснования. Такое укрепление государства, определяемое исключительно защитой «голой жизни», казалось бы, полностью лишает его политических оснований и локализации во времени. Однако любое возвращение к политике, связанное с неизбежным обострением внутренних конфликтов и растущей социальной поляризацией, приведет и к проблеме конечных целей государства. Представление о катехонеограниченном временем и миссией государстве-могут получить радикально противоположные, оппонирующие друг другу значения (и, как я демонстрирую в этой статье, имеющие глубокие основания в консервативной и социалистической традициях). 


\section{ЛИтеРАTУРA}

Булгаков С. Н. Апокалипсис Иоанна : опыт догматического истолкования. М. : Директ-Медиа, 2014.

Валиикий $A . B$. В кругу консервативной утопии. Структура и метаморфозы русского славянофильства. - М. : Новое литературное обозрение, 2019.

Гоббс Т. Левиафан, или материя, форма и власть государства церковного и гражданского / пер. с англ. А. Гутермана. - М. : Мысль, 2001.

Жирар Р. Я вижу Сатану, падающего, как молния / пер. с фр. А. Лукьянова, Х. О. - М. : Изд-во ББИ, 2015.

Канторович Э. Х. Два тела короля : исследование по средневековой политической теологии / пер. М.А. Бойцова, А. Ю. Серегиной. - 2-е изд. - М. : Институт Гайдара, 2015.

Кирилл [Патриарх Московский и всея Руси]. Подумайте о будущем человечества. - М. : Изд-во Московской патриархии, 2018.

Леонтъев К.Н. На могиле Пазухина // Антихрист (Из истории отечественной духовности) : Антология / под ред. А. С. Гришина, К. Г. Исупова. - М. : Высшая школа, 2012. - С. 99-102.

Лукач Д. Политические тексты / пер. с венгер., с нем. С. Земляного, Ю. Гусева. - М. : Три квадрата, 2010.

Маркс К. К еврейскому вопросу / пер. И. И. Прейса // Собрание сочинений. В 39 т. Т. 1 / К. Маркс, Ф. Энгельс ; пер. с нем. И. И. Прейса. - М. : Государственное издательство политической литературы, 1955. - С. 382-413.

Маркс К. 18 брюмера Луи-Бонапарта / пер. Л. И. Гольдмана, Н. Б. Тер-Акопяна // Собрание сочинений. В 39 т. Т. 8 / К. Маркс, Ф. Энгельс ; пер. с нем. Л. И. Гольдмана, Н. Б. Тер-Акопяна. - М. : Государственное издательство политической литературы, 1956а. - С. 115-217.

Маркс K. Экономико-философские рукописи 1844 года // Из ранних произведений / К. Маркс, Э. Ф. ; под ред. В. К. Брушлинским, Б. А. Крыловым, В. М. Познером ; пер. с нем. В. К. Брушлинского, Б. А. Крылова, В. М. Познера. М. : Высшая школа, 1956b. - С. 517-642.

Нойманн Ф. Бегемот. Структура и практика национал-социализма 1933-1945 / пер. с нем. В. Быстрова. - СПб. : Владимир Даль, 2015.

Поланъи K. Великая трансформация : политические и экономические истоки нашего времени / пер. с англ. А. А. Васильева, С. Е. Федорова, А.П. Шурбелева. - СПб. : Алетейя, 2015.

Сергиев, И. И. [Иоанн Кронштадтский]. Начало и конец нашего земного мира. Опыт раскрытия пророчеств Апокалипсиса. - СПб. : Лештуковская паровая скоропечатня П. О. Яблонского, 1900.

Шмитm K. Римский католицизм как политическая форма / пер. с нем. Ю. Коринца // Политическая теология. Сборник / сост. А. Филиппова. - М. : Канон-Пресс-Ц, Кучково поле, 2000. - С. 99-155. 
Шмитm K. Левиафан в учении о государстве Томаса Гоббса / пер. с нем. Д. В. Кузницына. - СПб. : Владимир Даль, 2006.

Шмитm K. Номос земли в праве народов Jus Publicum Europaeum / пер. с нем.

К. Лощевского, Ю. Коринца. - СПб. : Владимир Даль, 2008.

Agamben G. Stasis : Civil War as a Political Paradigm. - Edinburgh : Edinburgh University Press, 2015.

Fornari G. Figures of Antichrist : The Apocalypse and Its Restraints in Contemporary Political Thought // Contagion : ournal of Violence, Mimesis, and Culture. - 2010. - Vol. 17. - P. 52-85.

Horsley R. A. Paul and Empire. Religion and Power in Roman Imperial Society. London : Bloomsbury, 1997.

Kraft A. The Last Roman Emperor "Topos" in the Byzantine Apocalyptic Tradition // Byzantion. - 2012. - Vol. 82. - P. 213-257.

Manenschijn G., Vriend J. "Jesus Is the Christ": The Political Theology of "Leviathan" // The Journal of Religious Ethics. - 2012. - Vol. 25, no. 1. - P. 35-64. Milbank J. Theology and Social Theory. Beyond Secular Reason. - Oxford : Blackwell, 2006.

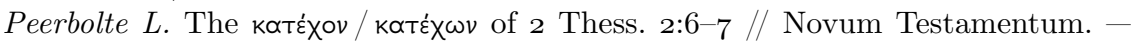
1997. - Vol. 39. - P. 138-150.

Polanyi K. Fascist Virus / Karl Polany. - 2010. - URL: http://kpolanyi.scool aid.net:8080/xmlui/handle/10694/658 (visited on Mar. 3, 2021).

Prozorov S. Like a Thief in the Night // Security Dialogue. - 2017. - Vol. 48, no. 6. - P. $473^{-487}$.

Rumlu C. Between Ambition and Quietism : The Socio-political Background of 1 Thessalonians 4,9-12 // Biblica. - 2010. - Vol. 91, no. 3. - P. 393-417.

White J. Anti-Imperial Subtexts in Paul : An Attempt at Building a Firmer Foundation // Biblica. - 2019. - Vol. 90, no. 3. - P. 305-333.

Wilde M. de. The Political Theologies of Walter Benjamin and Carl Schmitt // Philosophy \& Rhetoric. - 2011. - Vol. 44, no. 4. - P. $3^{6} 3^{-} 3^{81}$.

Williamson A.H. Apocalypse Then : Prophecy and the Making of the Modern World. - Westport, CT : Praeger, 2008.

Wilson B. M. Counterrevolutionary Polemics : Katechon and Crisis in de Maistre, Donoso, and Schmitt // The Philosophical Journal of Conflict and Violence. 2019. - Vol. 3, no. 2. - P. $73^{-} 95$. 
Budraitskis, I. B. 2021. "Chto 'uderzhivayet' katekhon? Konechnost' gosudarstva v konservativnoy i sotsialisticheskoy mysli [What is 'Restrained' by the katechon? The Finitude of the State in Conservative and Socialist Thought]" [in Russian]. Filosofiya. Zhurnal Vysshey shkoly ekonomiki [Philosophy. Journal of the Higher School of Economics] 5 (2), 13-33.

\section{ILYA BUDRAITSKIS}

LECTURER

Moscow Higher School of Social and Economic Sciences (Moscow, Russia); SENIOR RESEARCHer

Center for Contemporary Political Studies, iOn Ranepa (Moscow, Russia); ORCID: 0000-0003-0781-849X

\section{What is "Restrained" By the Katechon? The Finitude of the State in Conservative and Socialist Thought}

Submitted: Mar. 04, 2021. Reviewed: Mar. 20, 2021. Accepted: Mar. 31, 2021.

Abstract: The concept of katechoni ("that which withholds"), essential to both the theological tradition and modern political philosophy, originates in Second Thessalonians by Paul the Apostle. This withholding force which resists the coming of the end times has often been identified with the Roman Empire (and later with the Christian imperial state), the latter seen as a protected space that enabled the spread of the Good Tidings. This mission of containment, on the one hand, endowed the state with a sacred character, but on the other, it marked the state's finitude and imperfection. By withholding time, the katechon does not remove but preserves contradictions and heterogeneity, accepting its incompleteness as the burden of its own mission. In its secularized form, the restraining state conceives of society as an antagonistic space of struggle and conflict, and the function of political power is linked to the establishment of a temporal equilibrium with historically contingent and relative forms. In conservative thought, the katechon state guards society from unifying equality and rationalization, and individuals from the illusion of perfection and moral harmony. The understanding of the state as a force that rises above the disparate elements of society and preserves it against its inherent chaos was also at the core of the Marxist concept of the state. This article, based on a wide range of authors (T. Hobbes, K. Marx, K. Schmitt, K. Leontiev, D. Agamben) will consider conservative and leftist interpretations of the state, which accept and develop the idea of katechon and its interpretations not directly connected with the concept of state power.

Keywords: katechon, Political Theology, Eschatology, Marxism, Conservatism, Secularization, Bonapartism, Caesarism.

DOI: $10.17323 / 2587-8719-2021-2-13-33$.

\section{REFERENCES}

Agamben, G. 2015. Stasis: Civil War as a Political Paradigm. Edinburgh: Edinburgh University Press.

Bulgakov, S. N. 2014. Apokalipsis Ioanna [The Apocalypse of John]: opyt dogmaticheskogo istolkovaniya [The Experience of Dogmatic Interpretation] [in Russian]. M.: DirektMedia.

Fornari, G. 2010. "Figures of Antichrist: The Apocalypse and Its Restraints in Contemporary Political Thought." Contagion: ournal of Violence, Mimesis, and Culture 17:52-85. 
Girard, R. 2015. Ya vizhu Satanu, padayushchego, kak molniya [Je vois Satan tomber comme l'éclair] [in Russian]. Trans. from the French by A. Luk'yanov and Khmelevskaya O. M.: Izd-vo BBI.

Hobbes, Th. 2001. Leviafan, ili materiya, forma i vlast' gosudarstva tserkovnogo i grazhdanskogo [Leviathan or The Matter, Forme and Power of a Commonwealth Ecclesiasticall and Civil] [in Russian]. Trans. from the English by A. Guterman. M.: Mysl'.

Horsley, R. A. 1997. Paul and Empire. Religion and Power in Roman Imperial Society. London: Bloomsbury.

Kantorowicz, E.H. 2015. Dva tela korolya [The King's Two Bodies]: issledovaniye po srednevekovoy politicheskoy teologii [A Study in Medieval Political Theology] [in Russian]. 2nd ed. Trans. by M. A. Boytsov and A. Yu. Seregina. Moskva [Moscow]: Institut Gaydara.

Kirill [Patriarch of Moscow and all Rus']. 2018. Podumayte o budushchem chelovechestva [Think About the Future of Humanity] [in Russian]. M.: Izd-vo Moskovskoy patriarkhii.

Kraft, A. 2012. "The Last Roman Emperor 'Topos' in the Byzantine Apocalyptic Tradition." Byzantion 82:213-257.

Leont'yev, K. N. 2012. "Na mogile Pazukhina [On the Grave of Pazukhin]" [in Russian]. In Antikhrist (Iz istorii otechestvennoy dukhovnosti) [Antichrist (From the History of Russian Spirituality)] : Antologiya [Anthology], ed. by A. S. Grishin and K. G. Isupov, 99-102. Moskva [Moscow]: Vysshaya shkola.

Lukács, D. 2010. Politicheskiye teksty [Political Texts] [in Russian]. Trans. from the Hungarian and from the German by S. Zemlyanoy and Yu. Gusev. M.: Tri kvadrata.

Manenschijn, G., and J. Vriend. 2012. "'Jesus Is the Christ': The Political Theology of 'Leviathan'." The Journal of Religious Ethics 25 (1): 35-64.

Marx, K. 1955. "K yevreyskomu voprosu [Zur Judenfrage]" [in Russian]. In vol. 1 of Sobraniye sochineniy [Collected Works], by K. Marks and F. Engel's, trans. from the German by I. I. Preys, 382-413. 39 vols. Moskva [Moscow]: Gosudarstvennoye izdatel'stvo politicheskoy literatury.

_ 1956a. "18 bryumera Lui-Bonaparta [Der achtzehnte Brumaire des Louis Bonaparte]" [in Russian]. In vol. 8 of Sobraniye sochineniy [Collected Works], by K. Marks and F. Engel's, trans. from the German by L. I. Gol'dman and N. B. Ter-Akopyan, 115-217. 39 vols. Moskva [Moscow]: Gosudarstvennoye izdatel'stvo politicheskoy literatury.

_ 1956b. "Ekonomiko-filosofskiye rukopisi 1844 goda [Ökonomisch-philosophische Manuskripte aus dem Jahre 1844)]" [in Russian]. In Iz rannikh proizvedeniy [From Early Works], by K. Marx and F. Engels, ed. and trans. from the German by V. K. Brushlinskiy, B. A. Krylov, and V. M. Pozner, 517-642. Moskva [Moscow]: Vysshaya shkola.

Milbank, J. 2006. Theology and Social Theory. Beyond Secular Reason. Oxford: Blackwell. Neumann, F. 2015. Begemot. Struktura i praktika natsional-sotsializma 1933-1945 [Behemoth. Struktur und Praxis des Nationalsozialismus 1933-1944] [in Russian]. Trans. from the German by V. Bystrov. Sankt-Peterburg [Saint Petersburg]: Vladimir Dal'.

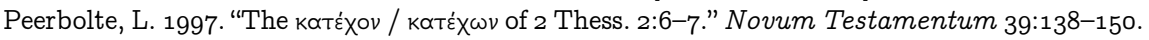

Polanyi, K. 2010. "Fascist Virus." Karl Polany. Accessed Mar. 3, 2021. http://kpolanyi.sco olaid.net:8080/xmlui/handle/10694/658.

-2015. Velikaya transformatsiya [The Great Transformation]: politicheskiye i ekonomicheskiye istoki nashego vremeni [The Political and Economic Origins of Our Time] [in Russian]. Trans. from the English by A. A. Vasil'yev, S. Ye. Fedorov, and A. P. Shurbelev. Sankt-Peterburg [Saint Petersburg]: Aleteyya.

Prozorov, S. 2017. "Like a Thief in the Night." Security Dialogue 48 (6): 473-487. 
Rumlu, C. 2010. "Between Ambition and Quietism: The Socio-political Background of 1 Thessalonians 4,9-12." Biblica 91 (3): 393-417.

Schmitt, C. 2006. Leviafan v uchenii o gosudarstve Tomasa Gobbsa [Der Leviathan in der Staatslehre des Thomas Hobbes] [in Russian]. Trans. from the German by D. V. Kuznitsyn. Sankt-Peterburg [Saint Petersburg]: Vladimir Dal'.

. 2008. Nomos zemli v prave narodov Jus Publicum Europaeum [Der Nomos der Erde im Völkerrecht des Jus Publicum Europaeum] [in Russian]. Trans. from the German by K. Loshchevskiy and Yu. Korinets. Sankt-Peterburg [Saint Petersburg]: Vladimir Dal'.

Sergiyev, I. I. [Ioann Kronshtadt-skiy]. 1900. Nachalo i konets nashego zemnogo mira. Opyt raskrytiya prorochestv Apokalipsisa [The Beginning and the End of Our Earthly World. The Experience of Revealing the Prophecies of the Apocalypse] [in Russian]. Sankt-Peterburg [Saint Petersburg]: Leshtukovskaya parovaya skoropechatnya P. O. Yablonskogo.

Shmitt, K. 2000. "Rimskiy katolitsizm kak politicheskaya forma [Römischer Katholizismus und politische Form]" [in Russian]. In Politicheskaya teologiya. Sbornik [Political Theology. Collection], by C. Schmitt, comp. A. Filippov, trans. from the German by Yu. Korinets, 99-155. Moskva [Moscow]: Kanon-Press-Ts / Kuchkovo pole.

Valitskiy, A. V. 2019. V krugu konservativnoy utopii. Struktura i metamorfozy russkogo slavyanofil'stva [In the Circle of a Conservative Utopia. Structure and Metamorphoses of Russian Slavophilism] [in Russian]. M.: Novoye literaturnoye obozreniye.

White, J. 2019. "Anti-Imperial Subtexts in Paul: An Attempt at Building a Firmer Foundation." Biblica 90 (3): 305-333.

Wilde, M. de. 2011. "The Political Theologies of Walter Benjamin and Carl Schmitt." Philosophy \&6 Rhetoric $44(4)$ : 363-381.

Williamson, A. H. 2008. Apocalypse Then: Prophecy and the Making of the Modern World. Westport, CT: Praeger.

Wilson, B. M. 2019. "Counterrevolutionary Polemics: Katechon and Crisis in de Maistre, Donoso, and Schmitt." The Philosophical Journal of Conflict and Violence 3 (2): 73-95. 